\title{
FAKTOR STATUS GIZI BALITA DI DESA CIMANGGUNG KECAMATAN CIMANGGUNG KABUPATEN SUMEDANG TAHUN 2012 .
}

\author{
Oleh : \\ Upus Piatun Khodijah, S.ST., M.Kes dan Neni Nur'aini, Amd.Keb \\ AKADEMI KEBIDANAN RESPATI SUMEDANG \\ JI. Raya Bandung Cirebon KM.75 Tomo Sumedang Telp. (0233)664000 email: \\ akbidrespatisumedang@gmail.com
}

\section{A. ABSTRAK}

Masalah gizi anak balita sudah saatnya ditangani dengan lebih terintegrasi, melibatkan unsur masyarakat dan organisasi setempat, dengan meningkatkan kesadaran pentingnya pemantauan tumbuh kembang balita untuk mendeteksi kemungkinan adanya gangguan pertumbuhan yang akan menjadi tanda awal terjadinya masalah gizi. Masalah gizi pada anak jika tidak mendapatkan penanganan yang baik dapat berkontribusi terhadap angka kematian balita. Penelitian ini bertujuan untuk mengetahui faktorfaktor yang berhubungan dengan status gizi balita di Desa Cimanggung Kecamatan Cimanggung Kabupaten Sumedang Tahun 2012. Penelitian ini merupakan penelitian kuantitatif dengan pendekatan desain cross sectional. Sampel dalam penelitian ini adalah ibu yang mempunyai balita di Desa Cihanjuang Kecamatan Cimanggung dengan sebanyak 88 orang dengan teknik simple random sampling. Analisis yang digunakan adalah analisis univariat dan bivariat. Hasil penelitian sebagian besar pengetahuan responden tentang gizi balita cukup baik (56,8\%), sebagian besar ber pendapatan keluarga rendah $(71,6 \%)$, sebagian besar kecukupan energi defisit (73,9\%), sebagian besar kecukupan protein defisit (58,0\%), sebagian besar status gizi pada balita cukup baik (58,0\%), tidak ada hubungan antara pengetahuan ibu tentang gizi balita, pendapatan keluarga dan konsumsi pangan dengan status gizi balita di Desa Cimanggung Kecamatan Cimanggung Kabupaten Sumedang. Diharapkan petugas kesehatan lebih meningkatkan upaya promosi kesehatan melalui penyuluhan dan pemberian informasi untuk mencegah kejadian gizi kurang dan buruk, serta keaktifan ibu balita lebih dalam mencari informasi dan juga menghadiri kegiatan di posyandu agar ibu lebih memahami perkembangan gizi pada balita.

Kata Kunci : Status Gizi, Gizi Buruk, Balita,

\section{A. PENDAHULUAN}

Peningkatan kualitas sumber daya manusia (SDM) yang dilakukan secara berkesinambungan. Upaya peningkatan kualitas SDM dimulai dengan perhatian utama pada proses tumbuh kembang anak sejak pembuahan sampai dengan usia dewasa muda. Pada masa tumbuh kembang ini, pemenuhan kebutuhan dasar anak seperti perawatan dan makanan bergizi yang diberikan dengan penuh kasih sayang dapat membentuk SDM yang sehat, cerdas dan produktif. $^{1}$

Salah satu upaya cukup penting terhadap peningkatan kualitas SDM adalah upaya peningkatan status gizi masyarakat.
Status gizi masyarakat merupakan salah satu faktor yang menentukan kualitas hidup dan produktivitas kerja. Angka kematian yang tinggi pada bayi, anak balita, dan terganggunya perkembangan mental dan kecerdasan jika ditelusuri adalah akibat langsung maupun tidak langsung dari kekurangan gizi. $^{2}$

Permasalahan balita dengan status gizi buruk di Indonesia menjadi hambatan dalam tercapainya salah satu target pembangunan Millenium Development Goals (MDGs), yaitu menurunkan Angka Kematian Bayi (AKB) menjadi 23 per 1.000 pada tahun 2015. Hasil Survey Demografi Kesehatan Indonesia (SDKI) tahun 2007 menyebutkan 
Angka Kematian Bayi (AKB) di Indonesia sebesar 34 per 1.000 kelahiran hidup dan Angka Kematian Balita (AKABA) sebesar 44 per 1.000 kelahiran hidup. AKB di Provinsi Jawa Barat sebesar 39 per 1.000 kelahiran hidup dan AKABA sebesar 49 per 1.000 kelahiran hidup. ${ }^{1}$

Tiga penyebab utama kematian bayi yaitu Infeksi Saluran Pernafasan Akut (ISPA), komplikasi perinatal, dan diare. Sementara penyebab utama kematian balita juga hampir sama yaitu penyakit saluran pernafasan, diare, penyakit saraf, termasuk meningitis, encephalitis dan typus. Penyebab utama kematian bayi dan balita tersebut semuanya berhubungan dengan status gizi bayi dan balita yang buruk. ${ }^{3}$

Pada tahun 2005 tercatat jumlah anak balita yang terkena gizi buruk melonjak dari 1,8 juta menjadi 2,3 juta anak pada tahun 2006. Dalam kurun waktu itu, lebih dari 5 juta balita terkena gizi kurang, bahkan 10\% berakhir dengan kematian. Prevalensi (temuan kasus berbanding jumlah balita) pun cenderung meningkat dari tahun ke tahun. Pada tahun 2008 dengan jumlah balita sekitar 28 juta, prevalensi balita dengan status gizi buruk berdasarkan berat badan sebesar $5,4 \%$ (sekitar 1,5 juta balita), balita dengan status gizi kurang sebesar $13,0 \%$ (sekitar 3,6 juta balita), balita dengan status gizi baik sebesar 77,2\% (sekitar 21,6 juta balita), dan balita dengan status gizi lebih sebesar 4,3\% (sekitar 1,3 juta balita). Kondisi ini sangat memprihatinkan karena mengancam kualitas SDM di masa yang akan dating. ${ }^{1}$

Status gizi buruk di Jawa Barat angka juga masih tinggi. Tercatat sampai Februari 2006 didapatkan 24.430 anak di bawah lima tahun yang mempunyai status gizi buruk yang terdiri dari 24.211 kasus lama $(99,1 \%)$ dan 219 (0,9\%) kasus baru. Pada tahun 2008 penderita gizi buruk balita sebanyak 38.760 $(1,09 \%)$ dan gizi kurang sebanyak 380.673
$(10,76 \%)$ dari jumlah 3.536 .981 balita yang ditimbang.+

Masalah gizi anak balita sudah saatnya ditangani dengan lebih terintegrasi, melibatkan unsur masyarakat dan organisasi setempat, dengan meningkatkan kesadaran pentingnya pemantauan tumbuh kembang balita untuk mendeteksi kemungkinan adanya gangguan pertumbuhan yang akan menjadi tanda awal terjadinya masalah gizi. ${ }^{3}$

Masalah kesehatan balita penanggulangannya tidak dapat dilakukan dengan pendekatan medis atau pelayanan kesehatan saja tetapi juga dengan pemantauan tumbuh kembangnya. Di posyandu telah disediakan Kartu Menuju Sehat (KMS) yang juga bisa digunakan untuk memprediksi status gizi anak berdasarkan kurva KMS. Namun sampai sejauh ini, kurangnya partisipasi masyarakat terhadap program-program yang sudah dilakukan menjadi kendala dalam upaya menurunkan kasus gizi buruk yang terjadi di Indonesia. $^{2}$

Masalah gizi disebabkan oleh berbagai faktor yang pada akhirnya mengakibatkan anak tidak mendapat asupan gizi yang cukup selama kurun waktu yang lama. Apabila dikaji penyebabnya akan sangat banyak dan tidak berkaitan langsung dengan sektor kesehatan. Salah satu faktornya dapat disebabkan oleh pengetahuan orang tua tentang gizi, pendapatan yang rendah dan pemilihan konsumsi pangan yang tidak tepat sehingga asupan gizi untuk anak tidak mencukupi dan akhirnya menimbulkan masalah gizi buruk. ${ }^{5}$

Berdasarkan data Dinas Kesehatan Kabupaten Sumedang tahun 2011 terdapat puskesmas dengan angka gizi buruk tertinggi yaitu Puskesmas Cimanggung sebesar 871 kasus gizi buruk, kemudian Puskesmas Tanjungsari sebesar 797 kasus gizi buruk, dan Puskesmas Sumedang Utara sebanyak 587 kasus gizi buruk. Sementara berdasarkan data dari Puskesmas 
Cimanggung tahun 2011 dari 11 Desa yang ada di wilayah kerjanya terdapat Desa dengan angka kejadian gizi kurang tertinggi yaitu di Desa Cimanggung sebesar 69 kasus gizi kurang. ${ }^{6}$

Berdasarkan latar belakang diatas, maka penulis tertarik untuk melakukan penelitian tentang "Faktor-faktor yang berhubungan dengan status gizi balita di Desa Cimanggung Kecamatan Cimanggung Kabupaten Sumedang Tahun 2012."

\section{B. METODOLOGI PENELITIAN}

Jenis penelitian ini adalah penelitian kuantitatif dengan pendekatan desain crosssectional untuk mendapatkan tentang hubungan antara pengetahuan, pendapatan dan konsumsi pangan dengan status gizi pada balita di Desa Cimanggung Kecamatan Cimanggung Kabupaten Sumedang. Populasi adalah keseluruhan subjek yang ada dalam wilayah penelitian. ${ }^{7}$ Populasi dalam penelitian ini adalah seluruh ibu yang mempunyai balita di Desa Cihanjuang Kecamatan Cimanggung dengan jumlah 879 orang. Pengambilan sampel untuk penelitian, jika subjeknya kurang dari 100 orang sebaiknya diambil semuanya, jika subjeknya besar atau lebih dari 100 orang dapat diambil $10-15 \%$ atau $20-25 \%$ atau lebih. ${ }^{8}$ Dalam penelitian ini penulis mengambil sampel $10 \%$ dari seluruh jumlah populasi, sehingga didapatkan sampel sebanyak 87,9 atau dibulatkan menjadi 88 orang. Teknik pengambilan sampel dilakukan dengan dua tahap yang pertama menghitung jumlah sampel berdasarkan area probability sample yaitu teknik sampling yang dilakukan dengan mengambil wakil dari setiap wilayah yang terdapat dalam populasi dan teknik simple random sampling yaitu pengambilan sampel secara acak sederhana. $^{9}$ Pengumpulan datanya menggunakan kuesioner dan analisis datanya meliputi analisis univariat menggunakan distribusi frekuensi dan bivarat menggunakan uji chi square.

\section{HASIL PENELITIAN \\ 1. Gambaran Lokasi Penelitian}

Desa Cimanggung merupakan salah satu desa yang berada di wilayah Cimanggung Kabupaten Sumedang. Desa Cimanggung terletak antara $6^{0} 44^{\prime}-70^{\circ} 83^{\prime}$ Lintang Selatan dan $107^{0} 21^{\prime}-108^{0} 21^{\prime}$ 'Bujur Timur, dengan luas wilayah $771.000 \mathrm{~m}^{2}$, yang terdiri dari 3 Dusun dengan 20 Rukun Warga (RW) dan 60 Rukun Tetangga (RT). Desa Cimanggung memiliki batas wilayah administratif sebagai berikut:

Sebelah Utara : Desa Pasirmanjung dan Kec. Sumedang Selatan

Sebelah Timur : Desa Tegalmanggung

Sebelah Selatan : Kab. Bandung

Sebelah Barat : Desa Sindangpakuon

Penduduk Desa Cimanggung berdasarkan data terakhir hasil Sensus Penduduk tahun 2010 tercatat sebanyak 9.620 jiwa. Pada tahun 2012 tercatat tenaga kesehatan di Desa Cimanggung terbagi atas medis/dokter 1 orang, keperawatan 2 orang, bidan 5 orang dan dukun beranak 4 orang

\section{Karakteristik Responden}

Karakteristik responden dalam penelitian ini meliputi pendidikan dan pekerjaan ibu balita yang dapat dilihat pada tabel berikut: 
Tabel 1

Karakteristik Responden berdasarkan Pendidikan dan Pekerjaan

\begin{tabular}{|c|c|c|}
\hline Karakteristik & Jumlah & $\%$ \\
\hline \multicolumn{3}{|l|}{ Pendidikan } \\
\hline SD & 28 & 31,8 \\
\hline SMP & 31 & 35,2 \\
\hline SMA & 29 & 32,9 \\
\hline \multicolumn{3}{|l|}{ Pekerjaan } \\
\hline Pegawai Swasta & 8 & 9,0 \\
\hline Wiraswasta & 13 & 14,7 \\
\hline Buruh & 12 & 13,6 \\
\hline IRT & 55 & 62,5 \\
\hline Total & 88 & 100 \\
\hline
\end{tabular}

Berdasarkan tabel 1, dapat diketahui bahwa sebagian besar responden berpendidikan SMP yaitu sebanyak 31 orang $(35,2 \%)$ dan berdasarkan pekerjaan sebagian besar responden adalah ibu rumah tangga (IRT) sebanyak 55 orang $(62,5 \%)$. Hal ini menunjukkan bahwa sebagian besar responden berpendidikan SMP $(35,2 \%)$ dan tidak bekerja atau IRT $(62,5 \%)$

\section{Analisis Univariat}

a. Pengetahuan Ibu tentang Gizi Balita Pengetahuan ibu tentang gizi balita dapat dilihat pada taebl 2 sebagai berikut:

Tabel 2

Distribusi Frekuensi Berdasarkan Pengetahuan Ibu tentang Gizi Balita di Desa Cimanggung Kecamatan Cimanggung Kabupaten Sumedang

\begin{tabular}{|c|c|c|}
\hline $\begin{array}{l}\text { Pengetahuan Ibu tentang } \\
\text { Gizi Balita }\end{array}$ & $\mathbf{F}$ & $\%$ \\
\hline Baik & 50 & 56,8 \\
\hline Sedang & 36 & 40,9 \\
\hline Kurang & 2 & 2,3 \\
\hline Jumlah & 88 & 100 \\
\hline $\begin{array}{l}\text { Berdasarkan tabel } 2 \text { menunjukkan } \\
\text { bahwa dari } 88 \text { responden, sebagian besar } \\
\text { pengetahuan ibu tentang gizi balita di Desa }\end{array}$ & & $\begin{array}{l}\text { tentang pengertian, tujuan dan dampak jika } \\
\text { balita kekurangan gizi. }\end{array}$ \\
\hline $\begin{array}{l}\text { Cimanggung Kecamatan Cimanggung } \\
\text { Kabupaten Sumedang adalah baik }(56,8 \%) \text {. } \\
\text { Pengetahuan disini meliputi pengetahuan ibu }\end{array}$ & & $\begin{array}{l}\text { b. Pendapatan Keluarga } \\
\text { Pendapatan keluarga dapat dilihat } \\
\text { pada tabel di bawah berikut ini: }\end{array}$ \\
\hline
\end{tabular}


Tabel 3

Distribusi Frekuensi Berdasarkan Pendapatan Keluarga di Desa Cimanggung Kecamatan Cimanggung Kabupaten Sumedang

\begin{tabular}{|c|c|c|}
\hline Pendapatan Keluarga & $\mathbf{F}$ & $\%$ \\
\hline Tinggi & 25 & 28,4 \\
\hline Rendah & 63 & 71,6 \\
\hline Jumlah & 88 & 100 \\
\hline
\end{tabular}

Berdasarkan tabel 4 menunjukkan bahwa dari 88 responden, sebagian besar pendapatan keluarga di Desa Cimanggung Kecamatan Cimanggung Kabupaten Sumedang adalah rendah $(71,6 \%)$. c. Konsumsi Pangan

Gambaran konsumsi pangan pada responden dapat dilihat pada tabel berikut ini:

Tabel 4

Distribusi Frekuensi Berdasarkan Konsumsi Pangan di Desa Cimanggung Kecamatan Cimanggung Kabupaten Sumedang

\begin{tabular}{|c|c|c|}
\hline Konsumsi Pangan & $\mathbf{F}$ & $\%$ \\
\hline \multicolumn{3}{|l|}{ Kecukupan Energi } \\
\hline Baik & 3 & 3,4 \\
\hline Sedang & 9 & 10,2 \\
\hline Kurang & 11 & 12,5 \\
\hline Defisit & 65 & 73,9 \\
\hline \multicolumn{3}{|l|}{ Kecukupan Protein } \\
\hline Baik & 12 & 13,6 \\
\hline Sedang & 10 & 11,4 \\
\hline Kurang & 15 & 17,0 \\
\hline Defisit & 51 & 58,0 \\
\hline Jumlah & 88 & 100 \\
\hline
\end{tabular}

Berdasarkan tabel 5 menunjukkan bahwa dari 88 responden, sebagian besar kecukupan energi di Desa Cimanggung Kecamatan Cimanggung Kabupaten Sumedang tahun 2012 adalah defisit $(73,9 \%)$ dan sebagian besar kecukupan protein adalah defisit $(58,0 \%)$.

\section{d. Status Gizi Balita}

Pada tabel 5 dapat dilihat distribusi status gizi pada balita. 
Tabel 5

Distribusi Frekuensi Berdasarkan Status Gizi Balita di Desa Cimanggung Kecamatan Cimanggung Kabupaten Sumedang

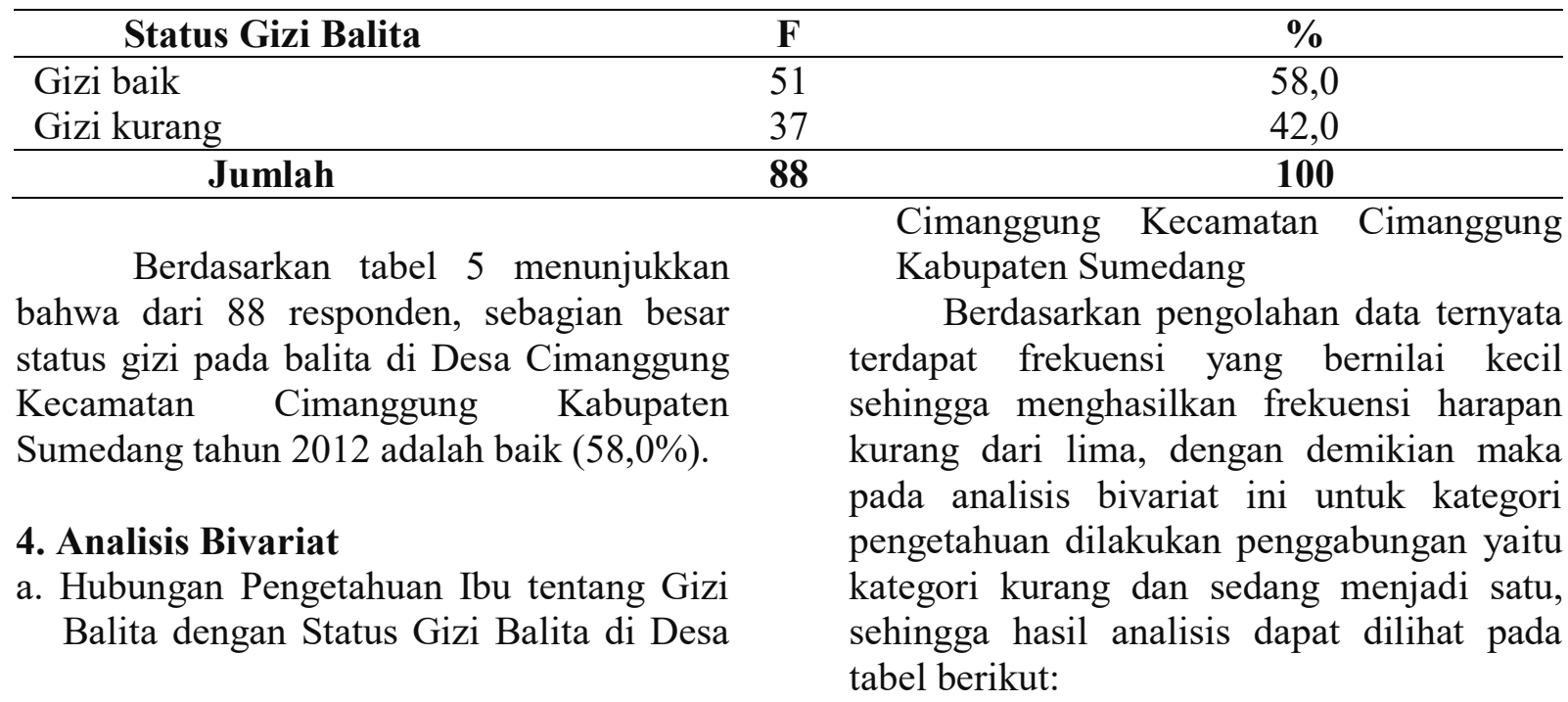

Tabel 6

Hubungan Pengetahuan Ibu tentang Gizi Balita dengan Status Gizi Balita di Desa Cimanggung Kecamatan Cimanggung Kabupaten Sumedang

\begin{tabular}{|c|c|c|c|c|c|c|c|}
\hline \multirow{3}{*}{$\begin{array}{c}\text { Pengetahuan ibu tentang } \\
\text { gizi balita }\end{array}$} & \multicolumn{4}{|c|}{ Status gizi balita } & \multirow{2}{*}{\multicolumn{2}{|c|}{ Total }} & \multirow{3}{*}{ Nilai $\mathbf{P}$} \\
\hline & \multicolumn{2}{|c|}{ Baik } & \multicolumn{2}{|c|}{ Kurang } & & & \\
\hline & $\mathrm{N}$ & $\%$ & $\mathrm{~N}$ & $\%$ & $\mathrm{n}$ & $\%$ & \\
\hline Baik & 29 & 58,0 & 21 & 42,0 & 50 & 100 & \multirow{2}{*}{1,000} \\
\hline Kurang & 22 & 57,9 & 16 & 42,1 & 38 & 100 & \\
\hline Jumlah & 51 & 58,0 & 37 & 42,0 & 88 & 100 & \\
\hline
\end{tabular}

\section{Keterangan : $\boldsymbol{\alpha}=\mathbf{0 , 0 5}$}

Berdasarkan tabel 6 menunjukkan bahwa proporsi responden dari 50 ibu dengan pengetahuan tentang gizi balita baik terdapat balita dengan status gizi baik sebesar 58,0\% dan stauts gizi kurang sebesar $42 \%$, sementara dari 38 ibu dengan pengetahuan tentang gizi balita kurang terdapat balita dengan status gizi baik sebesar $57,9 \%$ dan status gizi kurang sebesar $42,1 \%$.

Hasil penghitungan statistik dengan uji chi square pada $\alpha=0,05$ didapatkan $\mathrm{p}$ hipotesis nol gagal ditolak. Dengan demikian maka secara statistik menyatakan bahwa tidak ada hubungan antara pengetahuan ibu tentang gizi balita dengan status gizi balita di Desa Cimanggung Kecamatan Cimanggung Kabupaten Sumedang tahun 2012.

b. Hubungan Pendapatan Keluarga dengan Status Gizi Balita di Desa Cimanggung Kecamatan Cimanggung Kabupaten Sumedang 
Tabel 7

Hubungan Pendapatan Keluarga dengan Status Gizi Balita di Desa Cimanggung Kecamatan Cimanggung Kabupaten Sumedang

\begin{tabular}{ccccccccc}
\hline & \multicolumn{4}{c}{ Status gizi balita } & \multirow{2}{*}{ Total } & \multirow{2}{*}{ Nilai P } \\
\cline { 2 - 6 } Pendapatan keluarga & \multicolumn{3}{c}{ Baik } & \multicolumn{4}{c}{ Kurang } & \multicolumn{1}{c}{} \\
\cline { 2 - 6 } & $\mathbf{n}$ & $\mathbf{\%}$ & $\mathbf{N}$ & $\mathbf{\%}$ & $\mathbf{N}$ & $\mathbf{\%}$ & \\
\hline Tinggi & 16 & 64,0 & 9 & 36,0 & 25 & 100 & \multirow{2}{*}{0,628} \\
Rendah & 35 & 36,5 & 28 & 44,4 & 63 & 100 & \\
\hline Jumlah & $\mathbf{5 1}$ & $\mathbf{5 8 , 0}$ & $\mathbf{3 7}$ & $\mathbf{4 2 , 0}$ & $\mathbf{8 8}$ & $\mathbf{1 0 0}$ & \\
\hline
\end{tabular}

\section{Keterangan : $\boldsymbol{\alpha}=\mathbf{0 , 0 5}$}

Berdasarkan tabel 8 menunjukkan bahwa proporsi responden dari $25 \mathrm{ibu}$ dengan pendapatan keluarga tinggi terdapat balita dengan status gizi baik sebesar $64,0 \%$ dan stauts gizi kurang sebesar $36,0 \%$, sementara dari 63 ibu dengan pendapatan keluarga rendah terdapat balita dengan status gizi baik sebesar $36,5 \%$ dan status gizi kurang sebesar $42,4 \%$.

Hasil penghitungan statistik dengan uji chi square pada $\alpha=0,05$ didapatkan $\mathrm{p}$ value $=0,628(\mathrm{p}$ value $>0,05)$ yang berarti

hipotesis nol gagal ditolak. Dengan demikian maka secara statistik menyatakan bahwa tidak ada hubungan antara pendapatan keluarga dengan status gizi balita di Desa Cimanggung Kecamatan Cimanggung Kabupaten Sumedang tahun 2012.

c. Hubungan Konsumsi Pangan dengan Status Gizi Balita di Desa Cimanggung Kecamatan Cimanggung Kabupaten Sumedang

Tabel 8

Hubungan Konsumsi Pangan Berdasarkan Kecukupan Energi dengan Status Gizi Balita di Desa Cimanggung Kecamatan Cimanggung Kabupaten Sumedang

\begin{tabular}{|c|c|c|c|c|c|c|c|}
\hline \multirow{3}{*}{ Kecukupan Energi } & \multicolumn{4}{|c|}{ Status gizi balita } & \multirow{2}{*}{\multicolumn{2}{|c|}{ Total }} & \multirow{3}{*}{ Nilai $\mathbf{F}$} \\
\hline & \multicolumn{2}{|c|}{ Baik } & \multicolumn{2}{|c|}{ Kurang } & & & \\
\hline & $\mathbf{N}$ & $\%$ & $\mathbf{N}$ & $\%$ & $\mathrm{n}$ & $\%$ & \\
\hline Baik & 1 & 33,3 & 2 & 66,7 & 3 & 100 & \multirow{4}{*}{0,780} \\
\hline Sedang & 6 & 66,7 & 3 & 33,3 & 9 & 100 & \\
\hline Kurang & 6 & 54,5 & 5 & 45,5 & 11 & 100 & \\
\hline Defisit & 38 & 58,5 & 27 & 41,5 & 65 & 100 & \\
\hline Jumlah & 51 & 58,0 & 37 & 42,0 & 88 & 100 & \\
\hline
\end{tabular}

Keterangan : $\alpha=\mathbf{0 , 0 5}$

Berdasarkan tabel 9 menunjukkan bahwa proporsi responden dari 3 ibu dengan kecukupan energi baik terdapat balita dengan status gizi baik sebesar 33,3\% dan status gizi kurang sebesar $66,7 \%$, dari 9 ibu dengan kecukupan energi sedang terdapat balita dengan status gizi baik sebesar $66,7 \%$ dan status gizi kurang sebesar 33,3\%, dari $11 \mathrm{ibu}$ dengan kecukupan energi kurang terdapat balita dengan status gizi baik sebesar $54,5 \%$ dan status gizi kurang sebesar $45,5 \%$, sementara dari 65 ibu dengan kecukupan energi defisit terdapat balita 
dengan status gizi baik sebesar 58,5\% dan status gizi kurang sebesar $41,5 \%$.

Hasil penghitungan statistik dengan uji chi square pada $\alpha=0,05$ didapatkan $\mathrm{p}$ value $=0,780(\mathrm{p}$ value $>0,05)$ yang berarti hipotesis nol gagal ditolak. Dengan demikian maka secara statistik menyatakan bahwa tidak ada hubungan antara konsumsi pangan berdasarkan kecukupan energi dengan status gizi balita di n Cimanggung Kecamatan Cima 44 Kabupaten Sumedang. 
Tabel 9

Hubungan Konsumsi Pangan Berdasarkan Kecukupan Protein dengan Status Gizi Balita di Desa Cimanggung Kecamatan Cimanggung Kabupaten Sumedang

\begin{tabular}{|c|c|c|c|c|c|c|c|}
\hline \multirow{3}{*}{ Kecukupan Protein } & \multicolumn{4}{|c|}{ Status gizi balita } & \multirow{2}{*}{\multicolumn{2}{|c|}{ Total }} & \multirow{3}{*}{ Nilai $\mathbf{P}$} \\
\hline & \multicolumn{2}{|c|}{ Baik } & \multicolumn{2}{|c|}{ Kurang } & & & \\
\hline & $\mathbf{N}$ & $\%$ & $\mathbf{N}$ & $\%$ & $\mathbf{n}$ & $\%$ & \\
\hline Baik & 6 & 50,0 & 6 & 50,0 & 12 & 100 & \multirow{4}{*}{0,212} \\
\hline Sedang & 3 & 30,0 & 7 & 70,0 & 10 & 100 & \\
\hline Kurang & 9 & 60,0 & 6 & 40,0 & 15 & 100 & \\
\hline Defisit & 33 & 64,7 & 18 & 35,3 & 51 & 100 & \\
\hline Jumlah & 51 & 58,0 & 37 & 42,0 & 88 & 100 & \\
\hline
\end{tabular}

Keterangan : $\alpha=0,05$

Berdasarkan tabel 10 menunjukkan bahwa proporsi responden dari 12 ibu dengan kecukupan protein baik terdapat balita dengan status gizi baik sebesar 50,0\% dan status gizi kurang sebesar 50,0\%, dari $10 \mathrm{ibu}$ dengan kecukupan protein sedang terdapat balita dengan status gizi baik sebesar $30,0 \%$ dan status gizi kurang sebesar 70,0\%, dari 15 ibu dengan kecukupan protein kurang terdapat balita dengan status gizi baik sebesar 60,0\% dan status gizi kurang sebesar 40,0\%, sementara dari $51 \mathrm{ibu}$ dengan kecukupan protein defisit terdapat balita dengan status gizi baik sebesar 58,0\% dan status gizi kurang sebesar 35,3\%.

Hasil penghitungan statistik dengan uji chi square pada $\alpha=0,05$ didapatkan $p$ value $=$ 0,212 ( $p$ value $>0,05$ ) yang berarti hipotesis nol gagal ditolak. Dengan demikian maka secara statistik menyatakan bahwa tidak ada hubungan antara konsumsi pangan berdasarkan kecukupan protein dengan status gizi balita di Desa Cimanggung Kecamatan Cimanggung Kabupaten Sumedang.

\section{PEMBAHASAN}

Berdasarkan hasil penelitian menunjukkan bahwa sebagian besar ibu balita di Desa Cimanggung Kecamatan Cimanggung Kabupaten Sumedang berpengetahuan baik yaitu sebesar $56,8 \%$. Hal tersebut dapat dilihat dari jawaban responden pada pertanyaan tentang gizi balita. Banyaknya ibu balita yang berpengetahuan baik dapat dikarenakan ibu balita dalam memperoleh informasi juga baik dan juga dari segi pendidikan cukup baik. Hal tersebut dapat dilihat dari hasil pengumpulan data bahwa ibu balita yang berpendidikan SMA sebanyak 29 ibu balita $(32,9 \%)$.

Pengetahuan adalah hasil penginderaan manusia atau hasil tahu seseorang terhadap objek tertentu penginderaan terjadi melalui panca indera yang dimiliki (mata, hidung, telinga, dan sebagainya). Dengan sendirinya, pada waktu penginderaan sampai menghasilkan pengetahuan tersebut sangat dipengaruhi oleh intensitas perhatian dan persepsi terhadap objek. Sebagian besar pengetahuan seseorang diperoleh melalui indera pendengaran (telinga) dan indera penglihatan (mata). Pengetahuan seseorang terhadap objek mempunyai intensitas atau tingkat yang berbeda-beda. ${ }^{10}$

Upaya untuk meningkatkan pengetahuan ibu balita khususnya di Desa Cimanggung Kecamatan Cimanggung Kabupaten Sumedang adalah dengan cara meningkatkan promosi kesehatan oleh petugas kesehatan melalui kegiatan penyuluhan atau pemberian informasi secara berkesinambungan sehingga wawasan ibu balita bertambah.

Berdasarkan hasil peneli

menunjukkan bahwa sebagian besar ibu balita di Desa Cimanggung Kecamatan 
Cimanggung Kabupaten Sumedang berpendapatan rendah yaitu sebesar $71,6 \%$. Pendapatan yang rendah dan berbeda-beda setiap anggota keluarga dapat dikarenakan perbedaan jenis pekerjaan. Adanya tuntutan bekerja karena adanya kebutuhan keluarga yang harus dipenuhi terutama kebutuhan pokok.

Pendapatan adalah hasil aliran fisik dalam proses laba, yang didapat seseorang untuk proses kelangsungan ekonominya. Makanan sering digunakan untuk menunjukan prestasi dan status ekonomi. Semua budaya mempunyai makanan yang dianggap berprestise. Pendapatan adalah jumlah uang yang diterima oleh perusahaan dari aktivitasnya, kebanyakan dari penjualan produk dan atau jasa kepada pelanggan. Bagian investor, pendapatan kurang penting dibanding keuntungan, yang merupakan jumlah uang yang diterima setelah dikurangi pengeluaran. ${ }^{11}$

Pendapatan yang rendah perlu mendapatkan perhatian dari petugas kesehatan karena pendapatan yang rendah akan menyulitkan masyarakat untuk mendapatkan pelayanan kesehatan yang dibutuhkannya termasuk kebutuhan akan informasi kesehatan.

Berdasarkan hasil penelitian menunjukkan bahwa sebagian besar kecukupan energi di Desa Cimanggung Kecamatan Cimanggung Kabupaten Sumedang adalah defisit (73,9\%) dan sebagian besar kecukupan protein adalah defisit $(58,0 \%)$. Konsumsi pangan baik energi maupun protein yang defisit dapat dikarenakan oleh beberapa hal diantaranya adalah kurangnya informasi ibu tentang gizi dan juga dikarenakan kondisi perekonomian yang rendah yang dapat dilihat dari pendapatan keluarga yang rendah sehingga menyulitkan ibu memperoleh makanan yang bergizi.

Konsumsi pangan adalah segala sesuatu yang berasal dari sumber hayati dan air, baik yang diolah maupun tidak diolah, yang diperuntukkan sebagai makanan dan minuman bagi konsumsi manusia termasuk bahan tambahan pangan, bahan baku pangan, dan bahan lain yang digunakan dalam proses penyiapan, pengolahan dan atau pembuatan makanan dan minuman. ${ }^{12}$

Pada penelitian ini konsumsi pangan ibu yang diteliti adalah konsumsi protein dan energi. Hal ini dikarenakan kebutuhan protein dan energi pada anak sangat menentukan dalam masa perkembangannya. Kebutuhan energi dan protein ini di samping sebagai sumber energi, juga berfungsi sebagai bahan yang dibutuhkan dalam pertumbuhan dan perkembangannya, ataupun sebagai pengganti sel-sel yang rusak dan pertahanan tubuh. Kekurangan energi dan protein pada anak akan sangat mengganggu pertumbuhan dan perkembangan fisiknya, termasuk daya tahan terhadap penyakit serta perkembangan otak dan daya pikirnya di kemudian hari.

Ibu balita di Desa Cimanggung Kecamatan Cimanggung Kabupaten Sumedang yang mengalami defisit konsumsi pangan termasuk kebutuhan energi dan protein maka hal ini perlu mendapatkan perhatian oleh petugas kesehatan dengan cara memberikan penyuluhan dan pemberian informasi tentang konsumsi pangan yang baik bagi ibu balita dan juga bagi balitanya.

Berdasarkan hasil penelitian menunjukkan bahwa sebagian besar ibu balita di Desa Cimanggung Kecamatan Cimanggung Kabupaten Sumedang tahun 2012 dengan status gizi pada balita adalah baik yaitu sebesar $58,0 \%$. Banyaknya balita dengan gizi baik hal ini dapat dilihat dari berat badan terhadap tinggi badan balita termasuk normal. Meskipun demikian masih banyak balita yang mengalami gizi kurang yaitu $42,0 \%$ atau hampir mencapai setengahnya.

Status gizi adalah keadaan yang diakibatkan oleh status keseimbangan antara jumlah asupan (intake) zat gizi dan jumlah yang dibutuhkan (requirement) oleh tubuh untuk berbagai fungsi biologis: (pertumbuhan fisik, perkembangan, aktivitas, pemeliharaan kesehatan, dan lainnya). ${ }^{3}$ 
Balita yang mengalami gizi kurang di Desa Cimanggung Kecamatan Cimanggung Kabupaten Sumedang perlu menjadi bahan evaluasi bagi petugas kesehatan untuk meningkatkan kegiatan pemantauan pertumbuhan pada balita secara berkesinambungan yaitu dengan mengawasi kegiatan posyandu dalam penimbangan balita dapat berjalan dengan baik.

Berdasarkan hasil penelitian menyatakan bahwa tidak ada hubungan antara pengetahuan ibu tentang gizi balita dengan status gizi balita di Desa Cimanggung Kecamatan Cimanggung Kabupaten Sumedang. Hasil penelitian ini tidak membuktikan bahwa semakin baik pengetahuan ibu balita tentang gizi balita maka balita tidak akan mengalami gizi kurang atau buruk, dan sebaliknya bahwa semakin kurang pengetahuan ibu balita tentang gizi balita makan balita akan mengalami gizi kurang atau buruk. Hal tersebut berlawanan dengan teori Eveline dan Djamaludin pengetahuan ibu tentang tumbuh kembang balita seperti dalam pemilihan makanan yang bergizi bagi anaknya, pemberian imunisasi, kebersihan anak dan juga lingkungannya sangat berpengaruh pada pertumbuhan dan perkembangan anak yang berkualitas serta dapat mencegah gangguan anak pada masanya seperti gangguan bicara, autisme, retardasi mental dan bahkan cerebral palsy (kelainan postur dan gerakan). ${ }^{5}$

Berdasarkan hasil penelitian menyatakan bahwa tidak ada hubungan antara pendapatan keluarga dengan status gizi balita di Desa Cimanggung Kecamatan Cimanggung Kabupaten Sumedang. Hasil penelitian ini tidak membuktikan bahwa semakin tinggi pendapatan ibu maka status gizi balita semakin baik pula, dan sebaliknya semakin rendah pendapatan ibu maka status gizi balita semakin kurang atau buruk.

Hasil penelitian ini berlawanan dengan teori yang menyatakan bahwa salah satu sebab utama kurang gizi pada anak balita adalah rendahnya penghasilan keluarga. Ada keluarga yang sebenarnya penghasilannya cukup tetapi tidak bisa mengatur belanja keluarga dengan baik, akibatnya bahan makanan yang dibeli tidak mencukupi untuk keluarga. ${ }^{13}$ Ada juga keluarga yang membeli bahan pangan dalam jumlah cukup akan tetapi kurang pandai dalam memilih tiap jenis pangan yang dibeli akibatnya kurangnya mutu dan penggunaan pangan yang diperoleh. Dengan meningkatkan pendapatan terjadilah perubahan dalam susunan makanan. ${ }^{5}$

Berdasarkan hasil penelitian menyatakan bahwa tidak ada hubungan antara konsumsi pangan dengan status gizi balita di Desa Cimanggung Kecamatan Cimanggung Kabupaten Sumedang. Hasil penelitian ini tidak membuktikan bahwa semakin baik konsumsi pangan ibu balita maka status gizi balitanya semakin baik, dan sebaliknya semakin kurang baik konsumsi pangan ibu balita maka status gizi balitanya semakin kurang atau buruk.

Hasil penelitian ini berlawanan dengan teori yang menyatakan bahwa konsumsi pangan ibu dapat mempengaruhi status balita karena pemilihan makanan yang baik dan mengandung kebutuhan gizi bagi ibu terutama ketika masa kehamilan akan berdampak pada kelahiran bayi yang sehat. ${ }^{2}$

Tidak adanya hubungan pengetahuan ibu tentang gizi balita, pendapatan keluarga dan konsumsi pangan dengan status gizi balita dapat dikarenakan oleh beberapa faktor, yaitu: 1) Penelitian ini menggunakan desain cross sectional, maka tidak bisa menggambarkan kondisi status gizi, insiden, maupun prognosis karena hanya dilakukan satu kali pengukuran, sehingga kemungkinan juga terjadi bias prevalen atau bias insiden. 2) Dalam pengambilan data penelitian ini menggunakan recall $2 \times 24$ jam sehingga kemungkinan terjadi bias recall, sebab responden belum tentu ingat makanan yang dikonsumsi di waktu lampau dan 3) Adanya fenomena ambang rangsang, yaitu responden tidak memberikan informasi yang sesuai dengan keadaan yang sebenarnya.

Dengan demikian maka hasil penelitian ini perlu menjadi bahan pertimbangan bagi peneliti yang akan datang 
dalam melakukan penelitian yang sejenis diantaranya adalah memperhatikan faktorfaktor lain yang berhubungan dengan status gizi. Disamping itu perlu diperhatikan desain penelitian dan besar sampel, diharapkan untuk peneliti yang akan datang jumlah sampel diperbesar agar lebih proporsional mewakili populasi sehingga dapat menghasilkan data yang lebih bermakna dan lebih akurat terhadap teori.

\section{E. SIMPULAN DAN SARAN}

Berdasarkan hasil analisis dan pembahasan mengenai faktor-faktor yang berhubungan dengan status gizi balita yang dilakukan di desa di Desa Cimanggung Kecamatan Cimanggung Kabupaten Sumedang dapat simpulkan bahwa:

1. Sebagian besar berpengetahuan tentang gizi balita baik $(56,8 \%)$, sebagian besar ber pendapatan keluarga rendah $(71,6 \%)$,

2. Sebagian besar kecukupan energi defisit $(73,9 \%)$, sebagian besar kecukupan protein defisit $(58,0 \%)$.

3. Sebagian status gizi pada balita baik $(58,0 \%)$,

4. Tidak ada hubungan antara pengetahuan ibu tentang gizi balita, penda. patan keluarga dan konsumsi pangan dengan status gizi balita di Desa Cimanggung Kecamatan Cimanggung Kabupaten Sumedang.

\section{G. DAFTAR PUSTAKA}

1. Depkes RI, 2004. Sistem Kesehatan Nasional. Jakarta: Departemen Kesehatan RI.
2. Supriasa, I, dkk. 2002. Penilaian Status Gizi. Jakarta : Buku Kedokteran EGC.

3. Almatsier, S. 2004. Prinsip Dasar Ilmu Gizi. Jakarta : PT Gramedia Pustaka Utama.

4. Dinas Kesehatan Provinsi Jawa Barat. 2009. Profil Kesehatan Provinsi Jawa Barat tahun 2009. Bandung: Dinas Kesehatan Provinsi Jawa Barat

5. Arisman, 2010. Buku Ajar Ilmu Gizi, Gizi dalam Daur Kehidupan Edisi 2. Jakarta: EGC.

6. Dinas Kesehatan Kabupaten Sumedang. 2011. Profil Kesehatan Kabupaten Sumedang tahun 2011. Sumedang: Dinas Kesehatan Kabupaten Sumedang.

7. Sugiyono. 2010. Metode Penelitian Pendidikan Pendekatan Kuantitatif, kualitatif, dan R \& D. Bandung: Alfabeta.

8. Arikunto, S. 2006. Prosedur Penelitian Suatu Pendekatan Praktek Edisi Revisi VI. Jakarta: Rineka Cipta.

9. Notoatmodjo, S. 2010 Metodologi Penelitian Kesehatan. Jakarta : PT Rineka Cipta.

10. Notoatmodjo, S. 2007. Promosi Kesehatan dan Ilmu Perilaku. Jakarta: Rineka Cipta.

11. Mitayami, dkk. 2010. Buku saku Ilmu Gizi. Jakarta: Trans Info Media

12. Suyatno. 2009. Survei Konsumsi Sebagai Indikator Status Gizi. at http://suyatno.blog.undip.ac.id/files/200 9/11/psg-survei-konsumsi.pdf

13. Sulistyoningsih, H. 2011. Gizi untuk Kesehatan Ibu dan Anak. Yogyakarta: Graha
Ilmu 